\title{
Damages in the economic torts
}

\author{
John Hughes*
}

This paper examines the principles governing the award of damages through actions in the economic torts. It applies those principles to industrial relations and examines the possible impact on such actions of the Labour Relations Act 1987.

\section{Introduction}

Until recently it was regarded as a truism amongst industrial commentators that few actions brought against unions in one or other of the economic torts ever came to final trial. These torts, although constantly in flux, conventionally comprise conspiracy, intimidation. inducement of breach of contract and interference by unlawful means (Fleming. 1983). The aim of most plaintiffs was to obtain an interlocutory injunction restraining unions from striking. Once an injunction was granted (as it usually was) it was ra re for the action to proceed further.

There were many reasons for a reluctance to pursue defendant unions for the recovery of damages. First, such a pursuit might ultimately be fruitless if the union lacked the ability to pay any sum awarded against it. For example, in 1984 the Railways Corporation sued the National Union of Railwaymen alleging losses of \$2 500000 per day (NZ Railways Corporation v National Union of Railwaymen of NZ). Secondly, the continuing action and its ultimate result might poison industrial relations between the union and the employer for considerably longer than the simple issuing of an injunction. Thirdly, the pursuit of one union through litigation of this kind might well lead to "sympathy" action by other unions which could cause economic damage to the plaintiff far in excess of the amount claimed in damages.

The paucity of cases in which damages have been awarded against unions in New Zealand is the more noticeable for 2 special features of New Zealand's industrial relations laws. The first is the absence of any "trades disputes" clause, protecting unions from liability in tort where this arises from a genuine industrial dispute. Secondly, there was the comprehensive range of illegalities surrounding industrial action provided by the now repealed Industrial Relations Act 1973 and s119B of the Commerce Act 1975 (which created an independent statutory tort of uncertain dimensions).

Against this background, the award in March of \$1.66 million damages against the Northern Storepersons and Packers Union at the suit of the Ford Motor Company understandably shocked the trade union movement and, one suspects, some employers. That award must be seen in context. It was made by Chilwell $\mathbf{J}$ after formal proof at a hearing not attended by the union. The award met the claim in full, including a claim for punitive damages, this being a common occurrence at undefended hearings. Subsequently Chilwell $\mathrm{J}$ set aside his earlier judgment, when it became apparent that the union had failed to attend the hearing after being mistaken as to the company's intentions in relation to the litigation (Billing: 21.4.87). Ironically, in the same week as the award of damages was made, the Ford Motor Company told the select committee hearing representations on the Labour Relations Bill that unions were "financial men of straw" so that damages actions were not a viable option in cases of illegal strikes (Billing: 31.3.87). The action now proceeds on a defended basis and gives rise to 2 questions.

* Senior Lecturer. Faculty of Law, University of Canterbury. 
First, what principles govern the award of damages in such cases? Secondly, how, if at all, will the transfer of such actions to the Labour Court under s242 of the Labour Relations Act 1987 affect the established principles?

\section{Established principles}

Because few cases in this field are brought to a final hearing, there are correspondingly few detailed principles concerning the measure of damages to be awarded. Although the question has never been settled authoritatively, the same principles seem to apply to each of the torts (McGregor, 1980).

Damages are assessed without reference to the rule in Hadley $v$ Baxendale, under which damage must be foreseeable at the time the contract was entered into. The measure of damages will be assessed as at the date the damage was suffered. Damages are at large, so that it is not necessary for the plaintiff to prove specific damage (Exchange Telegraph Co v Gregory), even though proof of damage remains at the heart of the action: "(The) whole process of assessing damages where they are "at large" is essentially a matter of impression and not addition" (Cassell \& Co Ltdv Broome). Damage may be inferred "if the breach which has been procured by the defendant has been such as must in the ordinary course of business inflict damage upon the plaintiff" (Goldsoll v Goldman). Thus in Bent's Brewery Co v Hogan a trade union official attempted to persuade the plaintiff s employees to disclose confidential information as to the plaintiff s profits and wages bill, with the aim of using the information in collective bargaining. The court held that damage could be inferred, in that the intended use of this information might lead to the plaintiffs being compelled to pay higher wages.

Where the tort is committed against the employer, the usual type of damage sustained will be loss of profits. As the Ford Motor Company case shows, such damages may be substantial, to the extent in some cases of exceeding the current value of a union's combined assets and income. Such loss may be caused directly, as where the loss is incurred on the contract in respect of which the defendant has procured a breach (the normal result of a ban). The loss may also arise prospectively where the plaintiff is prevented from making a profit on other contracts or, in the case of an employee, prevented from obtaining paid employment (Jones $v$ Fabbi). In Collie v True the plaintiff, an employee, was granted damages representing prospective loss where the union's pursuit of him was held to be likely to "blight" the remainder of his industrial life. An issue of remoteness of damage may well arise in such circumstances.

Once pecuniary loss has been established or inferred, the court will consider non-pecuniary losses such as distress or other injuries to feelings (Pratt $v$ BMA). Such losses may be hard to prove in the case of an individual employer whose commercial contract has been broken (Jones $v$ Fabbi). In the case of a corporate employer, there are obvious difficulties in maintaining such a claim. In Nauru Local Government Council v NZ Seamens Union, Ongley J declined to compensate a corporation for "indignity", although implying that in such a case damage to commercial reputation would be compensable. Injury to feelings may, of course, give rise to a successful claim where the plaintiff is an individual, such as a trade union member whose contract of employment has been interfered with by a trade union, its officials or members. In such a case there is a clear analogy with Pratt $v B M A$ where medical practitioners, whose practises the defendant union had tried to ruin, were awarded damages in respect of a long period of "humiliation and menace". In Huntley v Thornton. Harman J stated that the "persecution" of the plaintiff by union officials was a factor to be taken into account in awarding damages at large, and in O'Boyle v Liggett substantial compensatory damages were awarded in respect of the serious effect upon the plaintiff's quality of life over a prolonged period following what was found to be intimidation by fellow workers and union officials. Where the alleged mental distress arises from physical assault (perhaps as the result of breaking a picket line) then, as with bodily injury, an award of compensatory or aggravated damages is precluded by 527 of the Accident Compensation Act 1982. Exemplary damages, designed to punish the defendant rather than compensate the plaintiff, remain available in such cases (Donselaar v Donselaar). There is at present some doubt concerning the extent to which emotional "losses" resulting from incidents undesigned by the plaintiff(such as assaults) may be compensated in tort rather than under the Accident Compensation Act 1982 (Auckland City Council v Blundell).

The plaintiff may also claim for foreseeable or intended expenses incurred as a result of the defendant's actions. Thus in the Nauru Local Government Council case, where the defendant union induced the Fijian crew of the plaintiffs ship not to work the vessel, the plaintiff recovered in damages its expenditure incurred in the repatriation of the striking crew, the 
provision of a substitute crew, recommissioning expenses and Harbour Board charges. General damages were also awarded in respect of the necessary redeployment of management staff to deal with the dispute.

Reasonable steps must be taken by the plaintiff to mitigate his or her loss (British and Irish Steam Packet Ltd v Branigan). In Pete's Towing Services Ltd v Northern Industrial Union of Workers where the plaintiff could have avoided the loss by entering into negotiations with the union. Speight $\mathrm{J}$ held that the plaintiff had failed to take such reasonable steps. On the standard required, the judge stated that:

\section{What may be judged reasonable is a question of fact and too high a standard must not be set. Nor is the plaintiff obliged to jeopardise his business in rash enterprises, to start uncertain litigation, to destroy his existing rights or property, or prejudice his reputation.}

Where an individual worker has been dismissed as a result of union pressure, mitigation by obtaining employment in the same industry may be almost impossible. In Collie v True it was accepted that "the weight of the union interdiction would be likely to make itself felt in any industry where the plaintiff might try to obtain worthwhile work". In cases where the plaintiff has obtained new employment, regard will be had to the difference in wages between his or her old and new jobs (Morgan v Fry).

Exemplary, or punitive, damages are perhaps the most difficult component to quantify. Such damages are available in New Zealand in any case where the defendant acts in contumelious disregard of the plaintiff's rights (Taylor v Beere). So far, no reported case based on inducement of breach of contract has given rise to such an award, although a claim for exemplary damages was considered but rejected by Ongley J in the Nauru Local Government Council case, and in this respect Ongley J's judgment was upheld by the Court of Appeal. In $O$ Boyle $v$ Liggett and Others where the allegations were of conspiracy and intimidation by certain union officials and union members against the plaintiff, exemplary damages of $\$ 6400$ were awarded by the jury on the basis of what Roper J described as "the quite outrageous manner in which the defendants conducted themselves over a prolonged period".

\section{The potential impact of the Labour Relations Act 1987}

Section 242(1) of the Labour Relations Act 1987 provides that:

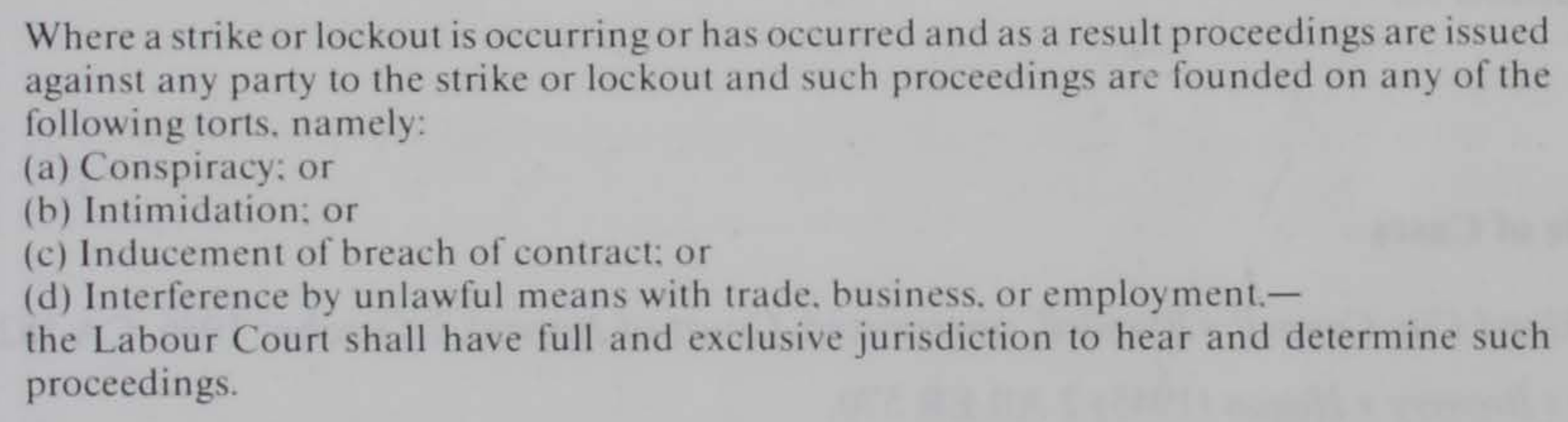

No other Court has jurisdiction in such cases (s 242(2)(3)). Under s 242(4) this jurisdiction is exercised by a Judge alone and urgency applies. The background to section 242 is exhaustively set out in the documents emerging from the Green Paper exercise (Industrial Relations: $A$ Framework for Review) and will not be canvassed here. Two features might be mentioned. First the Government, after toying with the idea of a "trades disputes" clause (a manifesto commitment in 1981), have abandoned that particular avenue. Secondly, in contrast to the position in the UK, there is no statutory limit on the size of awards of damages against trade unions (in Great Britain such a limit is imposed under s 16 of the Employment Act 1982 and varies according to the size of the union, the presumed object being to prevent the economic destruction of a defendant union). Nevertheless, the 1987 Act does create a limited category of lawful strikes under s 233, in respect of which no tort action may lie.

Some submissions on the Green Paper had argued for the transfer of this particular jurisdiction to the Labour Court on the basis that that court would apply a more rounded "industrial relations" approach to the issue than the common law courts (Industrial Relations: $A$ framework for review - summary of submissions, 63). Those submissions have been met only in part by section 242. Certainly, the Judge of the Labour Court will have more experience of industrial matters than his or her counterpart in the High Court. However, the "balancing" effect of lay members has been removed. Further, the flexible jurisdiction of the Labour Court 
in most matters before it to make decisions in equity and good conscience (s 27y) and to admit a wide range of evidence (s 303) does not extend to matters heard under s 292. Thus the Labour Court is left effectively with the principles established at common law, many of which date from an era when trade unions were seen as criminal conspiracies per se. Paradoxically, the Labour Court may find itself in the vanguard in establishing principles in these common law causes of action and it will be of considerable interest to see how the Court approaches grey areas such as the scope of the defence of justification.

Whether the transfer of this jurisdiction will increase or decrease the number of such cases remains to be seen. The view of this writer is that the greater publicity given to the availability of a remedy in tort, combined with employers ease of access to, and greater familiarity with, the Labour Court, will combine to produce a marked increase in the number of applications for remedies in tort. It may be that the Government, which must surely have been mindful of the detrimental effect of substantial awards against unions on the overall effectiveness of industrial courts, has taken a calculated risk that unions will tailor their coats to suit the new industrial cloth. At the time of writing, the New Zealand Engineers' Union is the only union to have publicly stated that it will now avoid strikes over disputes which may give rise to actions for damages. The judgment in the Ford Motor case must now be weighing on the minds of unions who have yet to commit themselves on the issue.

\section{References}

Billing. D Industrial Relations Commentary in the National business review.

Fleming, J G The Law of Torts Sydney, 1983, ch 29.

McGregor on Damages 14th ed, London, 1980.

New Zealand Government Industrial Relations: A framework for review, vols 1 and 2 Wellington, Government Printer, 1985, section 12.

Industrial Relations: A framework for review - summary of submissions Wellington, Government Printer, 1986, section 12.

Government Policy Statement on Industrial Relations Wellington, Government Printer, 1986, section 12.

\section{Table of Cases}

Auckland City Council v Blundell, unreported, Court of Appeal, 2 October 1986, CA 182/85. Bent's Brewery v Hogan (1945) 2 All ER 570.

British and Irish Steam Packet Ltd v Branigan (1958) IR 128.

Cassell \& Co Ltd v Broome (1972) AC 1027.

Collie v True (1959) 33 ALJR 224.

Donselaar v Donselaar (1982) 2 NZLR 97.

Exchange Telegraph Co v Gregory (1896) 118961 QB 147 (CA).

Goldsoll v Goldman (1914) 2 Ch 603.

Hadley v Baxendale (1854) 9 Exch 341.

Huntley v Thornton (1957) 1 All ER 234.

Jones v Fabbi (1973) 37 DLR (3d) 27.

Morgan v Fry (1968) 1 QB 521. Nauru Local Government Council v NZ Seamens Union, unreported, High Court. Wellington,
27 July 1982, A 583/73. 
Damages in the economic torts 105

New Zealand Railways Corporation v National Union of Railwaymen of NZ. unreported, High Court. Wellington. 1 June 1984, A 165/84.

New Zealand Seamen Union v Nauru Local Government Council, unreported, Court of Appeal. 11 July 1986. CA $63 / 83$.

O'Boyle v Liggett, unreported. High Court. Christchurch, 4 October 1982. A 174/81.

Pete's Towing Services Ltd v Northern Industrial Union of Workers (1970) NZLR 32.

Pratt v BMA (1919) 1 KB 244.

Taylor v Beers (1982) I NZLR 81. 